\title{
Remission in Goodpasture's syndrome: report of two patients treated by immunosuppression and review of the literature
}

\author{
ANTHONYSEATON, J. MILO MELAND, and N. LEROY LAPP \\ Department of Medicine, Cardiopulmonary Division, West Virginia University Medical Center, \\ Morgantown, West Virginia 26506
}

\begin{abstract}
Two patients with Goodpasture's syndrome are reported. One showed an apparently spontaneous remission and has survived in good health for over five years since the onset of his illness; he was treated for part of this time with steroids and chlorambucil. The second patient failed to respond to steroids but appeared to improve rapidly from a moribund state on administration of azathioprine; he remains well, although in mild renal failure, over a year later.

The management of 35 other patients reported to have survived this illness is reviewed. It appears that both the renal and pulmonary features of Goodpasture's syndrome may undergo spontaneous remission, and that the latter can sometimes be suppressed with steroid or immunosuppressant therapy. On four occasions the pulmonary manifestations of the disease have been arrested by nephrectomy.
\end{abstract}

Although Goodpasture's syndrome is usually thought to be a severe and rapidly fatal condition, a number of reports of survival have appeared in the literature. The disease appears to undergo spontaneous remissions and relapses. The purpose of this paper is to report two further survivors whose management included immunosuppressant therapy and to suggest that an aggressive therapeutic regimen may allow other patients with this illness to recover.

\section{CASE REPORTS}

CASE 1 A 57-year-old negro man was initially admitted on 19 May, 1966 with a one-month history of left-sided chest pain, breathlessness, and coughing up 2 to 3 teaspoonsful of blood daily for about five days. At this time he had a blood pressure of 140/80 $\mathrm{mmHg}$ and the only abnormalities on examination were fine basal crepitations. The haemoglobin was $12.2 \mathrm{~g} / 100 \mathrm{ml}$ and the blood count normal. The urine showed a trace of protein and 10 red cells/high-power field. The blood urea was $20 \mathrm{mg} / 100 \mathrm{ml}$. The chest radiograph showed patchy alveolar infiltrates in the left perihilar area and the right upper and mid zones. Bronchoscopy showed blood in the left main bronchus but bronchograms were normal. The patient recovered spontaneously and was discharged on tetracycline.

He was readmitted on 1 July, 1966 because of continued pink staining of the sputum, shortness of breath, and ankle oedema. Physical examination re- vealed evidence of congestive cardiac failure, and on this occasion his haemoglobin was found to be $5 \cdot 1$ $\mathrm{g} / 100 \mathrm{ml}$ and the reticulocyte count $1.4 \%$. The serum iron was $57 \mu \mathrm{g} / 100 \mathrm{ml}$, total iron-binding capacity $204 \mu \mathrm{g} / 100 \mathrm{ml}$, saturation $28 \%$. The white count was $3,200 / \mathrm{mm}^{3}$ with a normal differential. The blood urea had risen to $50 \mathrm{mg} / 100 \mathrm{ml}$ and the urine showed 50 red cells/high-power field. There was no laboratory evidence of any bleeding disorder or of gastrointestinal haemorrhage. The patient received 5 units of blood together with digitalis and diuretics and rapidly improved. The chest radiograph on this occasion showed a small right upper lobe alveolar infiltrate. A renal biopsy showed subacute proliferative glomerulonephritis, and haemosiderin-filled macrophages were seen in the sputum.

The patient's blood urea rose to a peak of $75 \mathrm{mg} /$ $100 \mathrm{ml}$ and then began to fall. At this time he was started on prednisone, $30 \mathrm{mg}$ daily. He has remained well, without haemoptysis, since then. On 12 May, 1967, coarse and granular casts and further red blood cells were found in the urine. He was started on chlorambucil, $4 \mathrm{mg}$ daily; this was reduced to $2 \mathrm{mg}$ daily in October 1967 and was stopped in February 1968. Reduction of the prednisone was started in July 1967 and this drug was stopped in January 1969. When last seen in October 1970, the patient was well, though his blood pressure had risen to $220 / 110$ $\mathrm{mmHg}$. The haemoglobin was $13.6 \mathrm{~g} / 100 \mathrm{ml}$, blood urea $19 \mathrm{mg} / 100 \mathrm{ml}$, and creatinine $1.9 \mathrm{mg} / 100 \mathrm{ml}$. The ESR was $29 \mathrm{~mm} /$ hour and the serum proteins were normal. The creatinine clearance was $71 \mathrm{ml} /$ 
minute. Traces of protein persisted in the urine but the chest radiograph was normal. Lung volumes, spirometry, and single breath transfer factor were normal at this time.

CASE 2 A 51-year-old white man was first seen on 3 November, 1969 with a history of shortness of breath, weakness, and an infiltrate having been seen on a chest radiograph. His blood urea was $22 \mathrm{mg} / 100$ $\mathrm{ml}$ but urinalysis and the blood count were normal. He was subsequently admitted on 14 May, 1970 with a three months' history of increasing fatigue, exertional dyspnoea, and coughing up small amounts of blood. Physical examination revealed no abnormalities other than pallor and fine basal crepitations. Blood pressure was $120 / 70 \mathrm{mmHg}$. Laboratory investigations showed $1.2 \mathrm{~g}$ proteinuria/24 hours, a haemoglobin of $7.8 \mathrm{~g} / 100 \mathrm{ml}$, and a blood sedimentation rate of $137 \mathrm{~mm} /$ hour. The reticulocyte count was $5 \%$, serum iron $46 \mu \mathrm{g} / 100 \mathrm{ml}$, ironbinding capacity $202 \mu \mathrm{g} / 100 \mathrm{ml}$, and saturation $23 \%$. The white cell count was $12,600,75 \%$ polymorphs and no eosinophils. The bone marrow showed diminished amounts of stainable iron. Urine microscopy showed 280 million red cells, 70 million white cells, and a large number of hyaline and granular casts per 12 hours. Plasma protein electrophoresis and electrolytes were normal. The rheumatoid factor and lupus erythematosus tests were negative. The blood urea was $44 \mathrm{mg} / 100 \mathrm{ml}$, creatinine clearance $31 \mathrm{ml} /$ minute, and an infusion intravenous pyelogram showed poor function in bilaterally enlarged kidneys. The chest radiograph showed a bilateral alveolar infiltrate in the middle and lower zones. Spirometry was normal. There was no evidence of blood loss other than into the lungs nor of any abnormality of blood coagulation. Renal biopsy showed subacute and chronic proliferative glomerulonephritis and a muscle biopsy was normal. Serum complement was normal, but there was a slight increase in $\beta_{1} \mathrm{~A} / \beta_{1} \mathrm{C}$ globulin to 210 (normal range $123-167$ ) $\mathrm{mg} / 100 \mathrm{ml}$.

He was treated with blood transfusion and prednisolone, $60 \mathrm{mg}$ daily. He felt better and his radiograph began to improve. However, two and a half weeks later he was readmitted with severe dyspnoea, profuse haemoptysis, and haematuria. The chest radiograph showed gross pulmonary haemorrhage (Fig. 1) and the blood urea was $130 \mathrm{mg} / 100 \mathrm{ml}$. The haemoglobin had fallen to $6.8 \mathrm{~g} / 100 \mathrm{ml}$. A blood transfusion was given and treatment with azathioprine, $200 \mathrm{mg}$ daily, was started on 17 June, 1970, when the patient appeared moribund. The steroids were gradually reduced and were eventually withdrawn on 12 August, 1970. The patient felt much less dyspnoeic and the haemoptysis stopped. The blood urea fell over three weeks to $22 \mathrm{mg} / 100 \mathrm{ml}$. The chest radiograph cleared rapidly over two weeks and has remained normal since (Fig. 2). Since this time, his condition has been good and he has been able to return to full-time employment on a $40 \mathrm{~g}$

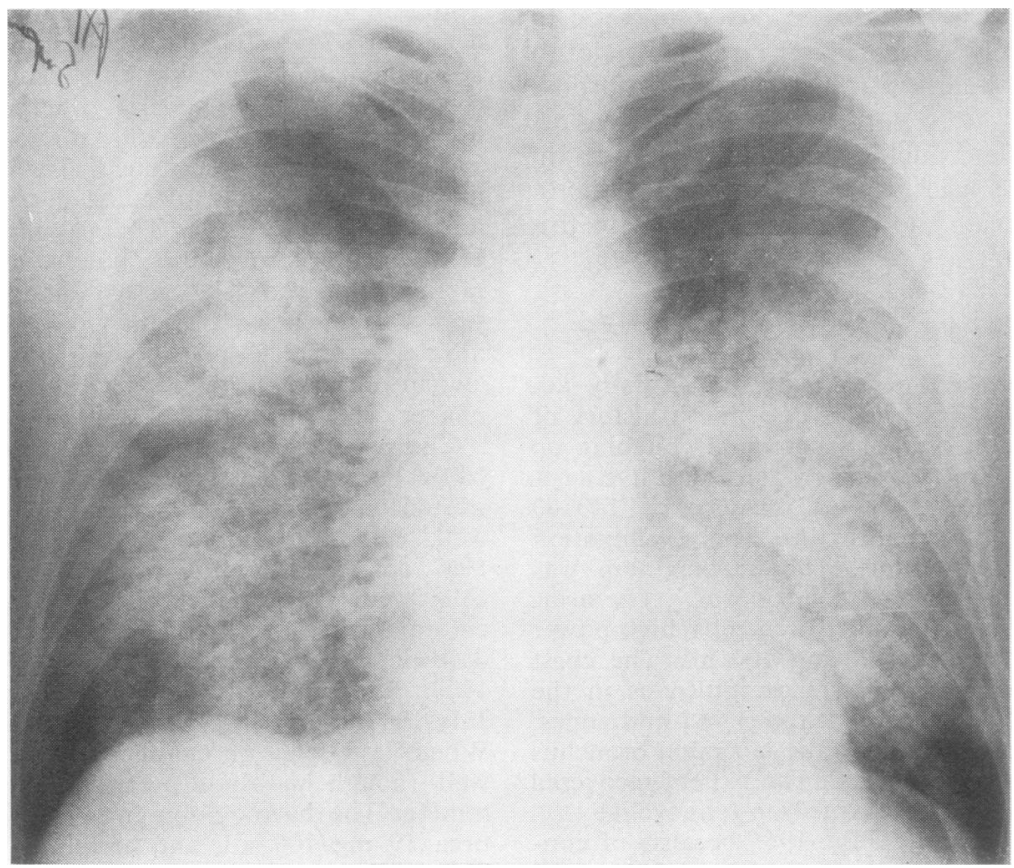

FIG. 1. Case 2. Chest radiograph on day of initiation of azathioprine therapy. 


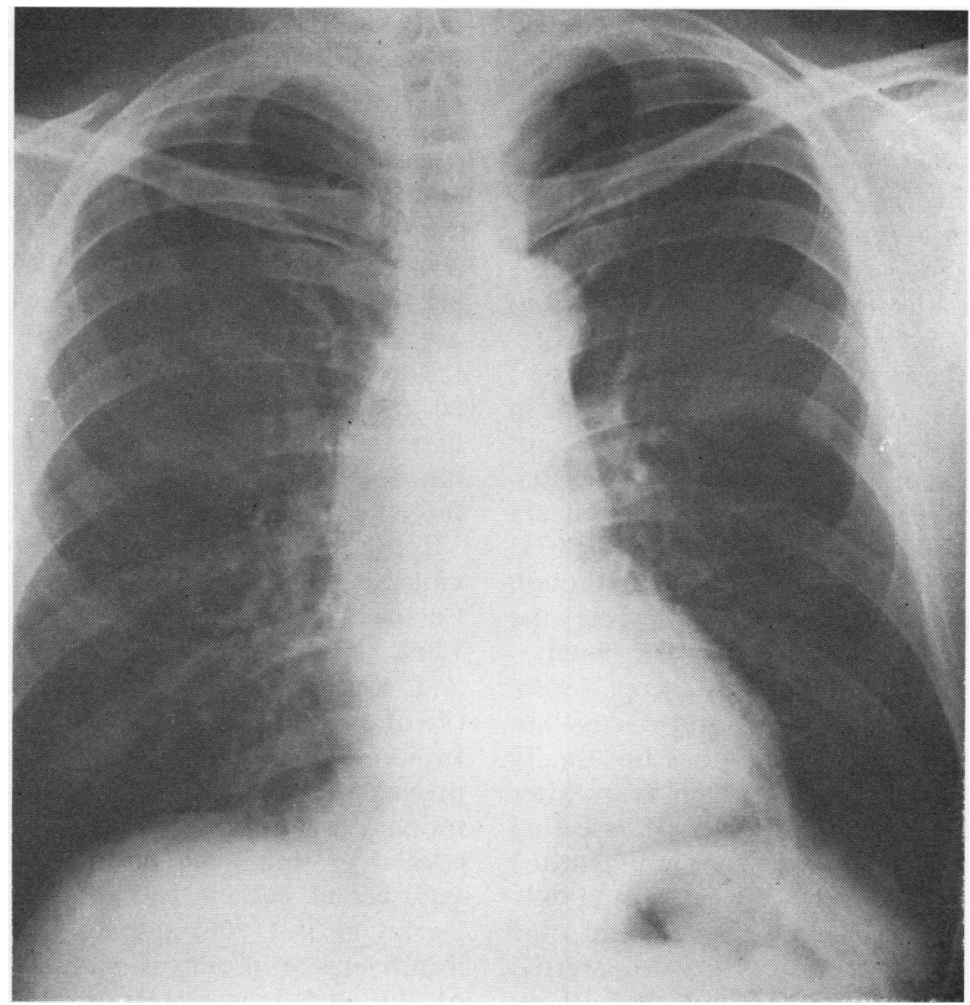

FIG. 2. Case 2. Chest radiograph after 4 weeks' therapy.

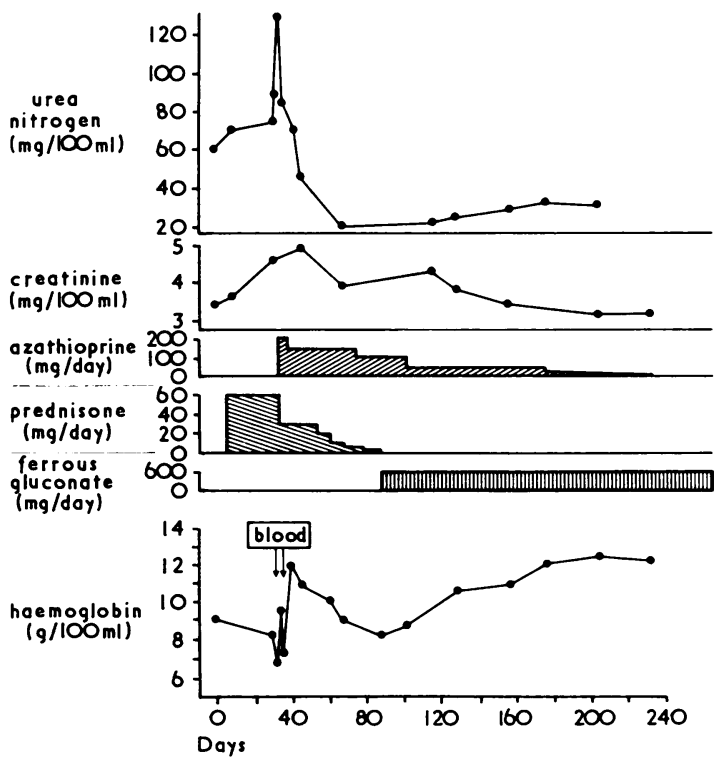

FIG. 3. Case 2. Summary of clinical course. protein, low salt diet. The azathioprine was reduced and finally stopped on 6 January, 1971. At this time the patient's blood pressure was $130 / 60 \mathrm{mmHg}$, blood urea $31 \mathrm{mg} / 100 \mathrm{ml}$, creatinine $3.3 \mathrm{mg} / 100 \mathrm{ml}$, creatinine clearance $43 \mathrm{ml} /$ minute, and 24 -hour protein excretion $3 \mathrm{~g}$; the urine showed no casts nor red cells. The haemoglobin gradually rose from $9 \cdot 1 \mathrm{~g}$ on 22 June. 1970, to $12.5 \mathrm{~g}$ on 9 December, 1970, when the sedimentation rate had fallen to $33 \mathrm{~mm} /$ hour. The clinical course is summarized in Figure 3.

\section{DISCUSSION}

Our two patients have been included as examples of Goodpasture's syndrome on the grounds that: (1) both had proliferative glomerulonephritis without arteritis on renal biopsy ; (2) both had severe iron-deficiency anaemia, and in neither was any dietary deficiency, coagulation disorder or gastrointestinal lesion discovered; and (3) both had persistent pulmonary haemorrhage with radiographic evidence of bilateral acinus-filling lesions.

As there are not yet any widely accepted pathological criteria for the diagnosis of this disease, it 
seems wise at present to consider it as a clinical syndrome which may have one or several pathological bases. This assumption has been made in reviewing the reports of patients with Goodpasture's syndrome who have apparently recovered or responded to treatment. As far as we are able to tell from the case reports, most of these subjects fulfilled the above criteria. In addition to the patients described above, we have been able to find reports of 35 patients who fit into this category. Eleven of these recovered spontaneously; clinical details and references are recorded in Table I. Several had only mild renal disease, but two were in acute renal failure. One of these two responded to dialysis alone and was well 13 months later (Munro, Geddes, and Lamb, 1967) ; the other remained anuric 22 months later though the pulmonary haemorrhage ceased while the renal failure was controlled by long-term haemodialysis (Freeman, Vertel, and Easterling, 1966). The patient reported by Scheer and Grossman (1964) had two spontaneous remissions but finally died of progressive renal failure seven years after the onset of the illness. The difficulty of assessing response to therapy in these patients is illustrated by the second patient described by Solberg (1969). This patient had four acute episodes in nine years ; the first two appeared to respond to steroid therapy but the others remitted similarly without any medication.

Fourteen patients are recorded as having recovered on steroid therapy (Table II). In some of these cases, the remission may well have been spontaneous (for example, Rusby and Wilson, 1960 ; Joseph, 1963 ; Walker and Joekes, 1963), though in others there appear to have been dramatic changes in the respiratory symptoms related to initiation or withdrawal of steroids (Solberg, 1969 ; Lehman and Cross, 1961). There is no convincing evidence that steroids have improved the renal lesion, and two of these patients are reported to have died of progressive renal failure three years (Lehman and Cross, 1961) and 20 months (Joseph, 1963) after diagnosis. Our first patient may well have undergone a spontaneous remission and it is impossible to assess the effect of therapy.

Immunosuppressant therapy has been used previously with success in five patients (Corley, Lessner, and Larsen, 1966 ; Campanacci et al., 1969 ; Everett et al., 1970 ; Michael et al., 1967) and antilymphocytic antiserum in one patient (Pirofsky, Bardana, Bayracki, and Porter, 1969). In some of these there has been evidence of improved renal function as well as cessation of pulmonary symptoms, though this is also true of several of those who improved spontaneously. In our second patient and the patients described by Corley et al. (1966) and Campanacci et al. (1969), improvement of very ill patients on administration of the immunosuppressants was so dramatic as to suggest a causal relationship. The patients reported by Everett et al. (1970) and Michael et al. (1967) responded less dramatically to this

T A B L E I

PATIENTS SHOWING SPONTANEOUS REMISSION

\begin{tabular}{|c|c|c|c|c|c|c|c|c|}
\hline \multirow{3}{*}{ Author } & \multirow{3}{*}{$\begin{array}{c}\text { Survival from } \\
\text { Onset to Time } \\
\text { of Report }\end{array}$} & \multicolumn{7}{|c|}{ Data at Time of Illness } \\
\hline & & \multirow{2}{*}{$\begin{array}{c}\text { Chest } \\
\text { Radiograph }\end{array}$} & \multirow[b]{2}{*}{ Haemoptysis } & \multicolumn{2}{|c|}{ Urine } & \multicolumn{3}{|c|}{ Blood } \\
\hline & & & & Protein & Blood & Hb $(g \%)$ & $\underset{(\mathrm{mm} / \mathrm{hr})}{\mathrm{ESR}}$ & $\begin{array}{l}\text { Urea } \\
(\mathrm{mg} \%)\end{array}$ \\
\hline Leff and Fazekas & - & - & Protracted & \multicolumn{5}{|c|}{ No clinical details } \\
\hline $\begin{array}{l}(1962) \\
\text { Benoit et al. (1964) }\end{array}$ & $30 \mathrm{mth}$ & Mottled hilar & Dark red & $30 \mathrm{mg} \%$ & $20 / \mathrm{hpf}$ & $4 \cdot 8$ & $一$ & 17 \\
\hline $\begin{array}{l}\text { Scheer and Grossman } \\
\text { (1964) }\end{array}$ & $12 \mathrm{yr}^{1}$ & $\begin{array}{l}\text { Infiltrates } \\
\text { Bilateral patchy } \\
\text { infiltrates }\end{array}$ & Recurrent & $34 \mathrm{~g} / 24 \mathrm{hr}$ & $50 / \mathrm{hpf}$ & $8 \cdot 0$ & - & Normal \\
\hline $\begin{array}{l}\text { Elder, Kirk and } \\
\text { Smith (1965) }\end{array}$ & $6 \mathrm{yr}$ & Diffuse mottling & Bloodstreaked & + & Many & $7 \cdot 7$ & - & Normal \\
\hline $\begin{array}{l}\text { McCall, Harris, and } \\
\text { Hatch (1965) }\end{array}$ & $18 \mathrm{mth}$ & $\begin{array}{l}\text { Soft patchy } \\
\text { densities }\end{array}$ & $\begin{array}{c}\text { Severe, bright } \\
\text { red }\end{array}$ & ++ & $++t$ & $11 \cdot 5$ & 15 & 22 \\
\hline $\begin{array}{l}\text { Pasternack, Linder, and } \\
\text { Kuhlbäck (1965) }\end{array}$ & $6 \mathrm{mth}$ & $\begin{array}{l}\text { Diffuse lower } \\
\text { zone opacities }\end{array}$ & Persistent & + & +++ & $7 \cdot 9$ & 98 & 一 \\
\hline Freeman et al. (1966) & $22 \mathrm{mth}$ & Bilateral hilar & Recurrent & +++ & Numerous & $9 \cdot 2$ & - & 159 \\
\hline Munro, Geddes, and & $13 \mathrm{mth}$ & Patchy basal & Persistent & Anuric & Anuric & $8 \cdot 7$ & 94 & 170 \\
\hline $\begin{array}{l}\text { Riegel and Dennis } \\
\text { (1967) }\end{array}$ & $2 \mathrm{mth}$ & $\begin{array}{l}\text { Alveolar } \\
\text { infiltrate }\end{array}$ & 'Haematemesis' & $4.62 \mathrm{~g} / 24 \mathrm{hr}$ & $222,000 / \mathrm{hr}$ & $\begin{array}{l}26 \\
\text { (haematocrit) }\end{array}$ & - & 90 \\
\hline Solberg (1969) (1) & $12 \mathrm{mth}$ & Central patchy & Recurrent & $30 \mathrm{mg} \%$ & $+t+$ & & 104 & 91 \\
\hline (2) & $9 \mathrm{yr}^{2}$ & $\begin{array}{c}\text { Basal patchy } \\
\text { consolidation }\end{array}$ & Persistent & Nil & Nil & $13 \cdot 0$ & 50 & 40 \\
\hline
\end{tabular}

${ }^{1}$ Before last remission. This patient had two remissions and finally died (see text).

${ }^{2}$ Before last remission. This patient had previous steroid-accompanied remissions (see text). 
T A B L E I I

PATIENTS TREATED WITH STEROIDS WHO SHOWED REMISSION

\begin{tabular}{|c|c|c|c|c|c|c|c|c|}
\hline \multirow{3}{*}{ Author } & \multirow{3}{*}{$\begin{array}{l}\text { Survival from } \\
\text { Onset to Time } \\
\text { of Report }\end{array}$} & \multicolumn{7}{|c|}{ Data at Time of Illness } \\
\hline & & \multirow{2}{*}{$\begin{array}{c}\text { Chest } \\
\text { Radiograph }\end{array}$} & \multirow{2}{*}{ Haemoptysis } & \multicolumn{2}{|c|}{ Urine } & \multicolumn{3}{|c|}{ Blood } \\
\hline & & & & Protein & Blood & $\mathrm{Hb}(\mathrm{g} \%)$ & $\underset{(\mathrm{mm} / \mathrm{hr})}{\mathrm{ESR}}$ & $\begin{array}{c}\text { Urea } \\
(\mathrm{mg} \%)\end{array}$ \\
\hline $\begin{array}{l}\text { Rusby and Wilson } \\
(1960) \\
\text { Fairley and Kincaid- } \\
\text { Smith }(1961)\end{array}$ & $\begin{array}{c}3 \mathrm{yr} \\
(3 \text { patients) }\end{array}$ & $\begin{array}{l}\text { Symmetrical } \\
\text { soft stippling }\end{array}$ & $\begin{array}{c}\text { Recurrent } \\
\text { staining } \\
\text { No clinical details }\end{array}$ & Present & Present & 8.6 & 28 & 36 \\
\hline Lehman and Cross & $3 \mathrm{yr}^{1}$ & $\underset{\text { infiltrates }}{\text { Hilar }}$ & Persistent & $++t$ & $50 / \mathrm{hpf}$ & $7 \cdot 4$ & - & 59 \\
\hline Joseph (1963) (1) & $32 \mathrm{mth}$ & & $\begin{array}{l}\text { Recurrent, } \\
\text { small }\end{array}$ & Present & 一 & $4 \cdot 6$ & - & 46 \\
\hline Schmidt et al. (1963) & $\begin{array}{c}20 \mathrm{mth}^{1} \\
(2 \text { patients })\end{array}$ & & No clinical details & & Present & - & & 一 \\
\hline $\begin{array}{l}\text { Walker and Joekes } \\
\text { (1963) }\end{array}$ & & Normal & & $380 \mathrm{mg} \%$ & $700,000 / \mathrm{hr}$ & $8 \cdot 6$ & - & 55 \\
\hline $\begin{array}{l}\text { Azen and Clatanoff } \\
(1964)\end{array}$ & 5 yr & $\begin{array}{l}\text { Diffuse } \\
\text { granular }\end{array}$ & $\begin{array}{c}\text { Recurrent } \\
\text { profuse }\end{array}$ & Present & Present & $5 \cdot 7$ & - & 40 \\
\hline $\begin{array}{l}\text { B]oom, Wayne, and } \\
\text { Wrong (1955) }\end{array}$ & $21 \mathrm{mth}$ & $\begin{array}{c}\text { Diffuse } 4 \mathrm{~cm} \\
\text { !esion } \mathrm{R} \text {. }\end{array}$ & Bright red & $7 \mathrm{~g} / 24 \mathrm{hr}$ & Many & $5 \cdot 5$ & - & 118 \\
\hline Duncan et al. (1965) & $2 \mathrm{yr}$ & $\begin{array}{l}\text { Patchy basal } \\
\text { infiltrates }\end{array}$ & Clots & ++ & + & $7 \cdot 6$ & 74 & 31 \\
\hline Heale et al. (1969) & $4 \mathrm{yr}$ & $\begin{array}{l}\text { Innitrates } \\
\text { Hazy lower } \\
\text { zones }\end{array}$ & Recurrent & $16 \mathrm{~g} / 24 \mathrm{hr}$ & Present & $5 \cdot 7$ & 13 & - \\
\hline
\end{tabular}

${ }^{1}$ Died of progressive renal failure.

therapy, though improvement was prolonged and well documented. The patient treated with antilymphocytic antiserum (Pirofsky et al., 1969) improved on this therapy, after treatment with steroids and immunosuppressants had failed, and was well eight months later. Immunosuppressant therapy is reported not to have altered the course of the disease in five other patients. One of these subsequently responded to renal surgery (Siegel, 1970), three were treated when in severe renal failure and did not respond (Duncan, Drummond, Michael, and Vernier, 1965 ; Heale, Matthiesson, and Niall, 1969), but one was treated at an early stage in the illness and his renal disease continued to progress (Holman, Hutt, Brittain, and Hammond, 1966).

There are reports of five patients treated by nephrectomy. Siegel (1970) reported a patient who had failed to respond to dialysis and immunosuppressive therapy and rejected a cadaveric renal graft. Subsequent removal of the three kidneys resulted in prompt resolution of the pulmonary symptoms. The patient then underwent a successful kidney graft and remained free of all symptoms 40 months later. Shires et al. (1968) reported two patients, whose pulmonary haemorrhage failed to respond to dialysis and ceased only after bilateral nephrectomy. They were subsequently treated with renal transplantation and immunosuppressants and remained free of symptoms after one and two years respectively. Maddock, Stevens, Reemtsma, and Bloomer (1967) reported a patient whose pulmonary haemorrhage continued unabated on steroids but stopped after nephrectomy with renal dialysis and reduction in the dose of steroids. Subsequent renal transplantation enabled him to remain well nine months later. One further patient is reported to have died after rejection of a kidney graft (Cleveland, Lee, Prout, and Hume, 1964). The details given in this report do not allow an assessment of his response.

Reports of unsuccessful management of Goodpasture's syndrome far outnumber those of patients who recovered. Many who died were treated with steroids, and the literature has recently been reviewed by Proskey et al. (1970) and previously by Benoit et al. (1964). In general, those patients who survive have less severe renal disease than those who do not. It must be suspected that many mild cases remit spontaneously and remain undiagnosed or unreported, and that the syndrome is probably less frequently fatal than would appear from published cases.

Progressive renal disease is usually responsible for the patient's death, though occasionally suffocation due to severe pulmonary haemorrhage has been the terminal event. In many patients, however, persistent anaemia due to pulmonary haemorrhage is an important cause of symptoms. Medical management of the renal failure alone has only rarely enabled remission to occur, the pulmonary haemorrhage usually continuing unabated. Steroids and immunosuppressants may sometimes arrest the pulmonary haemorrhage, but no therapy has been shown definitely to improve 
the renal lesion. In a disease which undergoes spontaneous remissions this is likely to be difficult to prove.

From a practical point of view, the patient fulfilling the criteria for Goodpasture's syndrome may be regarded as having a disease occasionally subject to spontaneous remissions. If remission does not occur, steroid treatment and, if necessary, dialysis should be instituted. The next step should probably be immunosuppressant therapy and, if this is not rapidly beneficial, consideration can be given to nephrectomy and dialysis or renal transplantation. It appears from the reported cases that it is the actual removal of the diseased kidneys rather than any of the other forms of management associated with nephrectomy and transplantation that leads to cessation of pulmonary haemorrhage. Many of these patients are relatively young and it is possible that an aggressive therapeutic programme could save more lives.

The authors thank Dr. Wilhelm Albrink for reporting on the renal biopsies and Mrs. Lynne Morris for assistance in the preparation of the paper.

\section{REFERENCES}

Azen, E. A., and Clatanoff, D. V. (1964). Prolonged survival in Goodpasture's syndrome. Arch. intern. Med., 114, 453.

Benoit, F. G., Rulon, D. B., Theil, G. B., Doolan, P. D., and Watten, R. H. (1964). Goodpasture's syndrome: a clinicopathologic entity. Amer. J. Med., 37, 424.

Bloom, V. R., Wayne, D. J., and Wrong, O. M. (1965). Lung purpura and nephritis (Goodpasture's syndrome) complicated by the nephrotic syndrome. Ann. intern. Med., 63, 752.

Campanacci, L., Castellani, A., Bazzato, G., Romagnoli, G. F., Rizzo, A., and Pidutti, F. (1969). Su di una osservazione di syndrome di Goodpasture (alveolite polmonare emorragica seguita da glomerulonefrite ad impronta rapidamente evolutiva). Singolare efficacia del trattamento con azatioprina. G. clin. Med., 50, 657 .

Cleveland, R. J., Lee, H. M., Prout, G. R., and Hume, D. M. (1964). Preservation of the cadaver kidney for renal homotransplantation in man. Surg. Gynec. Obstet. 119, 991.

Corley, C. C., Lessner, H. E., and Larsen, W. E. (1966). Azathioprine therapy of "autoimmune" diseases. Amer. J. Med., 41, 404.

Duncan, D. A., Drummond, K. N., Michael, A. F., and Vernier, R. L. (1965). Pulmonary hemorrhage and glomerulonephritis. Ann. intern. Med. 62, 920.

Elder, J. L., Kirk, G. M., and Smith, W. G. (1965). Idiopathic pulmonary haemosiderosis and the Goodpasture syndrome. Brit. med. J. 2, 1152.

Everett, E. D., Newcomer, K. L., Anderson, J., Bergin, J., and Overholt, E. L. (1970). Goodpasture's syndrome: response to mercaptopurine and prednisone. J. Amer. med. Ass., 213, 1849.

Fairley, K. F., and Kincaid-Smith, P. (1961). Goodpasture's syndrome. Brit. med. J. 2, 1646.
Freeman, R. M., Vertel, R. M., and Easterling, R. E. (1966). Goodpasture's syndrome: prolonged survival with chronic haemodialysis. Arch. intern. Med., 117, 643.

Heale, W. F., Matthiesson, A. M., and Niall, J. F. (1969). Lung haemorrhage and nephritis (Goodpasture's syndrome). Med. J. Aust., 2, 355.

Holman, R. E., Hutt, M. P., Brittain, R. S., and Hammond, W. S. (1966). Goodpasture's syndrome. Treatment failure with azathioprine. J. Amer. med. Ass., 196, 31.

Joseph, M. (1963). Nephritis with lung haemorrhage. Lancet, 1,1160 .

Leff, I. L., and Fazekas, G. (1962). Hemorrhagic and inter- N stitial pneumonitis with nephritis. Ann. intern. Med., o 56, 296.

Lehman, J. D., and Cross, K. R. (1961). Pulmonary hemosiderosis with glomerulonephritis. J. Iowa St. med. Soc., 51, 279.

Maddock, R. K., Stevens, L. E., Reemtsma, K., and Bloomer, H. A. (1967). Goodpasture's syndrome. Cessation of pulmonary hemorrhage after bilateral nephrectomy. Ann. intern. Med. 67, 1258.

McCall, C. B., Harris, T. R., and Hatch, F. E. (1965). Nonfatal pulmonary hemorrhage and glomerulonephritis. Amer. Rev. resp. Dis., 91, 424.

Michael, A. F., Vernier, R. L., Drummond, K. N., Levitt, J. I., Herdman, R. C., Fish, A. J., and Good, R. A. (1967). Immunosuppressive therapy of chronic renal disease. New Engl. J. Med., 276, 817.

Munro, J. F., Geddes, A. M., and Lamb, W. L. (1967). Goodpasture's syndrome: survival after acute renal failure. Brit. med. J., 4, 95.

Pasternack, A., Linder, E., and Kuhlbäck, B. (1965). @ Glomerulonephritis with initial pulmonary hemorrhage. Acta med. scand., 177, 601 .

Pirofsky, B., Bardana, E. J., Bayracki, C., and Porter, G. A. (1969). Antilymphocyte antisera in immunologically mediated renal disease. J. Amer. med. Ass., 210, 1059.

Proskey, A. J., Weatherbee, L., Easterling, R. E., Greene, J. A., and Weller, J. M. (1970). Goodpasture's syndrome: 으 a report of five cases and review of the literature. Amer. J. Med., 48, 162.

Riegel, N., and Dennis, M. (1967). Goodpasture's syndrome: A review with report of a possible case with apparent recovery. Amer. Rev. resp. Dis. 96, 96.

Rusby, N. L., and Wilson, C. (1960). Lung purpura with nephritis. Quart. J. Med., (N.S.) 29, 501.

Scheer, R. L., and Grossman, M. A. (1964). Immune aspects of the glomerulonephritis associated with pulmonaryo hemorrhage. Ann. intern. Med., 60, 1009.

Schmidt, H. W., Hargraves, M. M., Andersen, H. A., and N Daugherty, G. W. (1963). Pulmonary changes seen in lung purpura and some of the other collagen diseases. $N$ Canad, med. Ass. J., 88, 658.

Shires, D. A., Pfaff, W. W., DeQuesada, A., Miller, G. H $\omega$ and Cade, J. R. (1968). Pulmonary hemorrhage and glomerulonephritis. Arch. Surg., 97, 699.

Siegel, R. R. (1970). The basis of pulmonary disease resolu- $\frac{\mathscr{D}}{\mathscr{C}}$ tion after nephrectomy in Goodpasture's syndrome. Amer. J. med. Sci., 259, 201.

Solberg, C. O. (1969). Glomerulonephritis with initial lung purpura (Goodpasture's syndrome). Acta med. scand., 186, 401.

Walker, J. M., and Joekes, A. M. (1963). Survival after $\stackrel{\mathbb{\Phi}}{\Omega}$ haemoptysis and nephritis. Lancet, 2, 1199. 